\title{
Human Oral Epithelial Cells Impair Bacteria-Mediated Maturation of Dendritic Cells and Render T Cells Unresponsive to Stimulation
}

\author{
Magdalena Molero-Abraham ${ }^{1 \dagger}$, Jose L. Sanchez-Trincado ${ }^{1 \dagger}$, Marta Gomez-Perosanz ${ }^{1}$, \\ Alvaro Torres-Gomez ${ }^{1}$, Jose Luis Subiza ${ }^{2}$, Esther M. Lafuente ${ }^{1 * t}$ and Pedro A. Reche ${ }^{1 * t}$ \\ ${ }^{1}$ Department of Immunology, School of Medicine, Complutense University of Madrid, Madrid, Spain, ${ }^{2}$ Inmunotek SL, Madrid, \\ Spain
}

\section{OPEN ACCESS}

Edited by:

Eric Cox,

Ghent University, Belgium

Reviewed by:

Derek Young,

University of Kentucky, United States

Omar Kujan,

University of Western Australia,

Australia

${ }^{*}$ Correspondence:

Esther M. Lafuente

melafuente@med.ucm.es

Pedro A. Reche

parecheg@med.ucm.es

tThese authors have contributed equally to this work

Specialty section:

This article was submitted to Mucosal Immunity,

a section of the journal

Frontiers in Immunology

Received: 22 March 2019 Accepted: 07 June 2019

Published: 28 June 2019

Citation:

Molero-Abraham M

Sanchez-Trincado JL,

Gomez-Perosanz M, Torres-Gomez A,

Subiza JL, Lafuente EM and Reche PA

(2019) Human Oral Epithelial Cells Impair Bacteria-Mediated Maturation of Dendritic Cells and Render T Cells

Unresponsive to Stimulation.

Front. Immunol. 10:1434.

doi: 10.3389/fimmu.2019.01434
The oral mucosa is a first line of defense against pathogenic organisms and yet tolerates food antigens and resident bacteria. Mucosal epithelial cells are emerging as important regulators of innate and adaptive immune responses. However, the contribution of oral epithelial cells (OECs) determining oral immunity is understudied. Here, we evaluated the ability of H413 and TR146 cells, two OEC lines derived from human oral squamous cell carcinomas, and primary OECs to modulate immune responses to a cocktail of Gram ${ }^{+}$ and Gram ${ }^{-}$bacteria known as MV130. OECs expressed CD40 constitutively and class II major histocompatibility complex (MHC II) molecules when stimulated with IFN $\gamma$, but not CD80 or CD86. Dendritic cells (DCs) treated with bacteria in co-culture with OECs did not fully mature, as judged by the expression of MHC II, CD80 and CD86, and barely released $\mathrm{IL}-12$ and TNF $\alpha$, compared to control DCs. Furthermore, in the presence of OECs, DCs were unable to stimulate allogenic naive CD4 T cells to produce IFN $\gamma$ and TNF $\alpha$. Similarly, OECs in culture with total CD4 T cells or Th1 cells stimulated with anti-CD3 and anti-CD28 antibodies abrogated CD25 and CD69 expression, T cell proliferation and the release of IFN $\gamma$ and TNF $\alpha$. The inhibition on T cell activation by OECs was cell-contact dependent, TGF $\beta$ independent and largely irreversible. Overall, this behavior of OECs is likely key to avoid immune system over-reaction against resident bacteria.

Keywords: oral epithelial cells, dendritic cells, $\mathrm{T}$ cells, immunomodulation, bacteria

\section{INTRODUCTION}

The oral mucosa constitutes a physical barrier between the inner and outer environment and is in charge of orchestrating first line immune responses against pathogenic intruders and harmful substances (1). Interestingly, oral epithelial cells are also in contact with commensal species and food antigens that are tolerated by the immune system. The oral mucosa differs from other mucosae in that it includes a stratified epithelium consisting of several layers of squamous epithelial cells piling up on top of the lamina propria with increasing degree of keratinization. Embedded in the

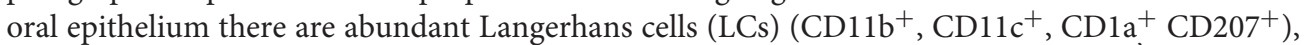
whereas the lamina propria contains myeloid DCs (mDCs) $\left(\mathrm{CD} 11 \mathrm{c}^{+}, \mathrm{CD} 209^{+}\right)$macrophages, plasma cells, B cells, and different subsets of T cells (1-3). 
Epithelial cells in the mucosae can act as initial sensors of danger and have a decisive role in determining immune responses (4). In general, residents DCs in the mucosae orchestrate defense and tolerance mechanisms after the environmental context provided by the surrounding epithelial cells (4-6). For instance, intestinal epithelial cells (IECs) contribute to the generation of $\mathrm{CD}_{103}{ }^{+}$DCs by releasing retinoic acid and TGF $(7)$. Likewise, IECs promote noninflammatory Th2 responses and Treg differentiation through the release of thymic stromal lymphopoietin (TSLP) $(8,9)$. This same cytokine is also produced by cryptic and squamous epithelial cells from inflamed tonsils and has been shown to trigger dendritic cell-mediated allergic inflammation (10).

Mucosal epithelial cells can also modulate $\mathrm{T}$ cell responses directly and act as non-professional antigen-presenting cells (4, 11-16). It has been shown that colonic, intestinal, and esophageal epithelial cells express MHC II and CD80/CD86 co-stimulatory molecules in response to IFN $\gamma$, working as non-professional antigen-presenting cells under pathological conditions (1114). Colonic epithelial cells and human biliary epithelial cells reduce antigen-mediated activation of CD4 $\mathrm{T}$ cells by unknown mechanisms requiring cell contact $(15,16)$. Also human renal tubular epithelial cells suppress alloreactive $\mathrm{T}$ cell proliferation in a contact-dependent manner (17). In addition, kidney, airway, thymic and colonic epithelial cells constitutively express CD40 indicating that these cells can directly be influenced by $\mathrm{T}$ cell responses $(15,18-20)$.

Oral epithelial cells (OECs) are also likely to control oral immune responses but such a role is understudied. In this work, we used primary OECs isolated from the oral cavity of healthy volunteers and two human oral epithelial cell lines-H413 and TR146 cells, both from oral squamous cell carcinomas-with the aim to analyze their ability to condition the immune responses to bacterial stimuli. A cocktail of $\mathrm{Gram}^{+}$and $\mathrm{Gram}^{-}$bacteria known as MV130 was used (21). Besides containing bacteria genera and species well-represented in oral cavities $(21,22)$, MV130 has in vivo immunomodulary properties (23), and stimulates DCs and promotes T cell polarization (21) in vitro. We found that OECs hampered the maturation of DCs, reducing MHC II, CD80 and CD86 expression, and inhibited IL-12, IL-10, and $\mathrm{TNF} \alpha$ secretion promoted by bacteria. Moreover, unlike DCs maturated with bacteria alone, DCs co-cultured with OECs were unable to induce the differentiation of IFN $\gamma$-producing CD4 T cells. Furthermore, OECs could directly impair the activation of CD4 T cells mediated by anti-CD3/CD28 antibodies, reducing CD25 and CD69 expression, T cell proliferation and IFN $\gamma$ secretion in a contact-dependent manner, pointing to an inherent ability of OECs to suppress immune responses.

\section{METHODS}

\section{Oral Epithelial Cells (OECs) and Bacterial Cocktail}

OEC lines H413 and TR146, derived from human oral squamous cell carcinomas, were acquired from the European Collection of Authenticated Cell Cultures (ECACC, Merck KGaA Darmstadt, Germany). Primary human OECs were obtained from voluntary healthy donors, as described by Michalczyk et al. (24), with slight modifications. All donors signed informed consent documents. We cultured $\mathrm{H} 413$ cells at $37^{\circ} \mathrm{C}$ and $5 \% \mathrm{CO}_{2}$ in DMEM:HAMS F12 (1:1, vol/vol) (Gibco, NY, USA) supplemented with $0.5 \mu \mathrm{g} / \mathrm{ml}$ hydrocortisone sodium succinate (Merck KGaA, Darmstadt, Germany), TR146 cells in DMEM (Gibco, NY, USA), and primary OECs in RPMI 1640 (Gibco, NY, USA). In all cases, media were supplemented with $10 \%$ fetal bovine serum (FBS) (Gibco NY, USA), $100 \mathrm{U} / \mathrm{ml}$ penicillin, $100 \mu \mathrm{g} / \mathrm{ml}$ streptomycin, and $2 \mathrm{mM}$ L-glutamine (Lonza, Walkersville, USA).

As bacterial stimuli, we used MV130 (Bactek ${ }^{\circledR}$, Inmunotek S.L., Spain), a cocktail of inactivated whole cell bacteria $\left(10^{9}\right.$ bacteria/ml) containing Staphylococcus aureus (15\%), Staphylococcus epidermidis (15\%), Streptococcus pneumoniae (60\%), Klebisella pneumoniae (4\%), Branhamella catarrhalis (3\%) and Haemophilus influenzae (3\%).

\section{OECs Stimulation and Preparation of OEC-Conditioned Media}

OECs were treated with $1,000 \mathrm{U} / \mathrm{ml} \mathrm{IFN \gamma}$ (Immunotools) or with MV130 (10 bacteria:1 OEC) for $48 \mathrm{~h}$ on 96 -well plates (2.5 $\times 10^{4}$ cells/well). To obtain the OEC-conditioned media, we collected OEC-culture supernatants, filtered them with a $0.22 \mu \mathrm{m}$ diameter pore size filter and stored them at $-20^{\circ} \mathrm{C}$ until further use. OECs and OEC-conditioned media (CM) treated with or without bacteria were subsequently used in cultures with DCs and/or T cells.

\section{Generation of DCs and Culture With OECs}

DCs used in this study consisted in human monocytederived dendritic cells. Briefly, we first obtained peripheral blood mononuclear cells (PBMCs) from buffy coats from the regional blood transfusion center (Centro de Transfusion de la Comunidad de Madrid (Madrid, Spain). Donors previously signed the informed consent document for the use of organs and/or tissues for research purposes, following the legislation corresponding to the Royal Decree-Law 1088/2005 of September 16 (reference number: BOE-A-2005-15514). PBMCs were isolated by a density gradient on Ficoll-Paque ${ }^{\mathrm{TM}}$ PLUS (Amershan) and subsequently purified $\mathrm{CD}_{1}{ }^{+}$monocytes by positive selection using magnetic beads coupled with an antiCD14 antibody (Miltenyi Biotec). CD14 ${ }^{+}$cells were plated on 24 -well plates $\left(1.5 \times 10^{6}\right.$ cells/well $)$ and incubated for 5 days in complete RPMI medium supplemented with $800 \mathrm{U} / \mathrm{ml}$ granulocyte-macrophage colony-stimulating factor (GM-CSF) and $400 \mathrm{U} / \mathrm{ml} \mathrm{IL-4}$ (Immunotools). The resulting immature DCs were used in experiments in which they were incubated on 96well plates $\left(10^{5}\right.$ cells/well) for $48 \mathrm{~h}$ with OECs ( 4 DC: 1 OEC) pretreated with or without stimuli (MV130) (10 bacteria:1 OEC).

\section{Stimulation of CD4 T Cells in Culture With OECs}

DCs were used to stimulate allogenic naive CD4 T cells purified from PBMCs using antibody-coupled magnetic beads (human CD4 T cell and naive CD4 T cell isolation kits, Miltenyi Biotec). CD4 $\mathrm{T}$ cells were plated on 96-well plates in complete RPMI medium $\left(2 \times 10^{5}\right.$ cells/well $)$ including: DCs $\left(1 \times 10^{5}\right.$ cells/well $)$ alone (controls) previously treated with or without MV130 for 
$48 \mathrm{~h}$ (10 bacteria:1 T cell), DCs and OECs treated or untreated with MV130 (8 T cell:4 DC:1 OEC). Cell cultures were then incubated at $37^{\circ} \mathrm{C}$ and $5 \% \mathrm{CO} 2$ for 6 days, adding $10 \mathrm{ng} / \mathrm{ml} \mathrm{IL-2}$ (Immunotools) every 2 days.

\section{CD3/CD28-Mediated Activation of CD4 T Cells in Culture With OECs or OEC-Conditioned Media}

We carried out antibody-stimulations on naive, total, and Th1 CD4T cells using anti-CD3/CD28 antibodies. Total and naive CD4 $\mathrm{T}$ cells were isolated from PBMCs as indicated previously. Th1 cells were generated from naive $\mathrm{T}$ cells by incubating them on 96 -well plates $\left(2 \times 10^{5}\right.$ cells/well $)$ with beads coupled with anti-CD3/CD28 antibodies (Dynabeads ${ }^{\circledR}$ Human T-activator CD3/CD28, ThermoFisher Scientific) in complete RPMI medium supplemented with $10 \mathrm{ng} / \mathrm{ml}$ IL12 (Immunotools) and $5 \mu \mathrm{g} / \mathrm{ml}$ anti-IL-4 antibody (SigmaMerck KGaA, Darmstadt, Germany). Subsequently, beads were removed following the manufacturer's instructions and Th1 cells were left resting for $6 \mathrm{~h}$. Naive, total or Th1 CD4 T cells were stimulated by incubating them on 96-well plates $(2 \times$ $10^{5}$ cells/well) in complete RPMI with Dynabeads ${ }^{\circledR}$ Human Tactivator for either $48 \mathrm{~h}$ for Th1 and total CD4 T cells or 6 days for naive $\mathrm{T}$ cells. For each CD4 T cell subset, antibodymediated stimulations were performed under three different experimental contexts: CD4 T cells alone (controls), with or without MV130 (10 bacteria:1 T cell); CD4 T cells in co-culture with OECs previously treated for $48 \mathrm{~h}$ with or without MV130 (8 T cell:1 OEC) and CD4 T cells with OEC-conditioned media, obtained as indicated before. In some experiments, CD4 T cells were re-activated with Dynabeads ${ }^{\circledR}$ Human T-activator after OEC co-culture.

\section{CD4 T Cell Proliferation and Apoptosis Assays}

Anti-CD3/CD28 activated CD4T cells were labeled with Carboxyfluorescein Diacetate Succinimidyl Ester (CFSE) (ThermoFisher) following the manufacturer's instructions and plated on 96-well cell-culture plates $\left(2 \times 10^{5}\right.$ cells/well $)$ in complete RPMI media with or without OECs (8 T cell:1 OEC), that were previously treated for $48 \mathrm{~h}$ with or without MV130. Plates were incubated at $37^{\circ} \mathrm{C}$ and $5 \% \mathrm{CO} 2$ for 7 days. Proliferation of CFSE-labeled CD4 T cells was monitored by flow cytometry (BD FACSCalibur). For apoptosis assays, anti-CD3/CD28 activated CD4 T cells in complete RPMI media on 96-well plates $\left(2 \times 10^{5}\right.$ cells/well $)$ were incubated alone or with OECs ( $8 \mathrm{~T}$ cell:1 OEC) previously treated with or without MV130. After $48 \mathrm{~h}$ of culture at $37^{\circ} \mathrm{C}$ and $5 \% \mathrm{CO} 2$, cell necrosis/apoptosis was assessed by flow cytometry (BD FACSCalibur) using Annexin V Apoptosis Detection Kit with 7-AAD (Biolegend).

\section{Analysis of Cell Surface Markers and Cytokine Production}

Cell surface markers expression on OECs, DCs, and CD4 T cells was analyzed by flow cytometry using the following antibodies and kits: anti-CD80 (L307.4), anti-CD83 (HB15e) and anti-CD86 (FUN-1), all from BD Pharmingen; anti-HLA-ABC (REA230), anti-HLA-DR (AC122), anti-CD83 (HB15), anti-CD40 (HB14) and anti-Cd11c (MJ4-27G12), all from Miltenyi-Biotech; antiCD25 (BC96) and anti-CD69 (FN50) (eBioscience) and FITC Annexin V Apoptosis Detection Kit with 7-AAD (Biolegend), following the manufacturer's instructions. Briefly, cells were washed with $0.5 \%$ BSA $/ 2$ mM EDTA in PBS (staining buffer), Fc receptors blocked with human IgG serum $(200 \mu \mathrm{g} / \mathrm{ml})$ (SigmaMerck) for $30 \mathrm{~min}$ at RT, and stained with the fluorescencelabeled antibodies. Cell markers expression was measured by flow cytometry (BD FACSCalibur) and data analysis was performed using FlowJo software (Tree Star).

IFN $\gamma, \quad$ TNF $\alpha$, TGF $\beta$, IL-1 $\beta$, IL-2, IL-4, IL-6 and IL-10 (Invitrogen), and IL-8 and IL-12 (Inmunotools) were quantified in cell-free supernatants using specific solid phase sandwich ELISA cytokine kits following the manufacturer's instructions. The resulting color was measured (BioTek ELx800 Absorbance Microplate Reader).

\section{TGF $\beta$ Blocking Assay}

We incubated H413 OECs on 96 -well plates $\left(2.5 \times 10^{5}\right.$ cells/well $)$ in complete RPMI in the presence or absence of MV130 for $48 \mathrm{~h}$. Subsequently, we added increasing concentrations $(20 \mathrm{ng} / \mathrm{ml}$, $300 \mathrm{ng} / \mathrm{ml}$ or $2.5 \mu \mathrm{g} / \mathrm{ml}$ ) of a blocking anti-TGF $\beta$ antibody (AntihTGF $\beta$-IgA, Invivogen) and after a $4 \mathrm{~h}$ incubation we added total CD4 T cells (8 T cell:1 OEC), previously activated with anti-CD3/CD28 beads (human T-activator CD3/CD28). We incubated the plates for $48 \mathrm{~h}$, and detected IFN $\gamma$ and TNF $\alpha$ levels by ELISA kits (Invitrogen).

\section{Statistical Analysis}

Data are expressed as the mean \pm standard error of the mean. We applied two-tailed Student's $t$-test for independent samples to assess statistical significance between means (Welch's test), assuming normality and heteroscedastic variances. $P<0.05$ was considered significant. Statistic calculations were performed on Microsoft Excel (2016).

\section{RESULTS}

\section{Cytokine Secretion and Expression of HLA-DR and Co-stimulatory Molecules by OECs}

We analyzed cytokine secretion in two human oral epithelial cell (OEC) lines derived from squamous cell carcinomas (H413 and TR146) and in primary OECs, obtained from the oral cavity of healthy volunteers. OECs were treated or untreated with a cocktail of whole cell heat-inactivated $\mathrm{Gram}^{+}$and Gram $^{-}$bacteria (MV130) (10:1, bacteria:OEC ratio). After $48 \mathrm{~h}$, the levels of IL-1 $\beta$, TNF $\alpha$, TGF $\beta$, IL-6, IL-8, and TSLP were determined in culture supernatants. As shown in Figure 1A, H413 and TR146 cell lines, but not primary OECs, constitutively secreted IL-6 and IL-8, and this secretion increased slightly under bacterial stimuli, whereas TNF $\alpha$ and IL- $1 \beta$ secretion remained unchanged before and after bacterial exposure. TGF $\beta$ was secreted by all cell types at similar levels and decreased in 

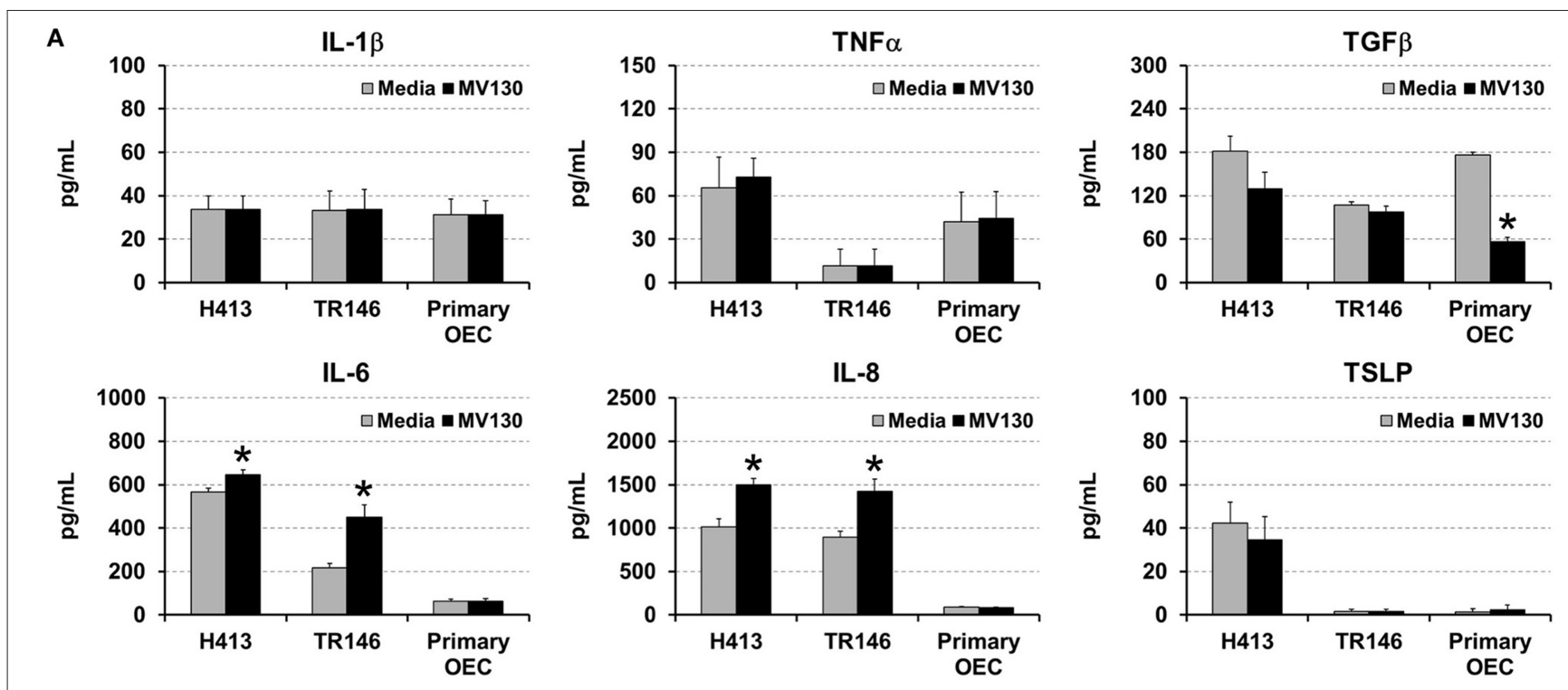

B

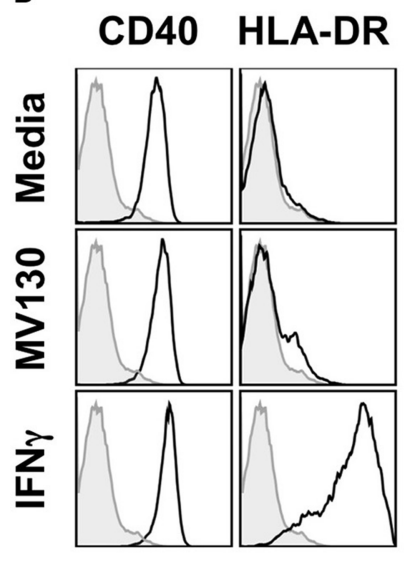

H413

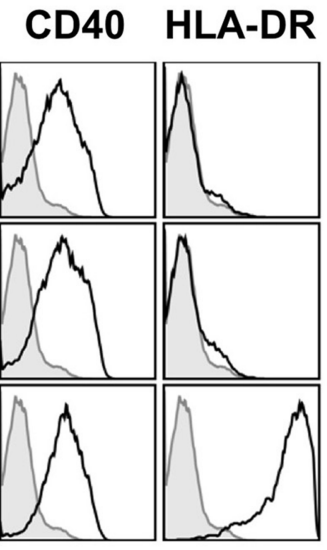

TR146

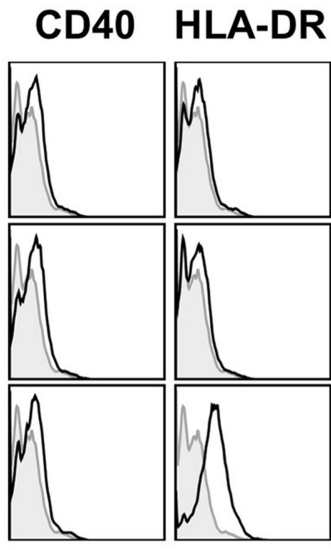

Primary OEC

FIGURE 1 | Cytokine secretion and surface markers expression in OECs. (A) Figure depicts the levels of various cytokines determined by ELISA on cell culture supernatants obtained from H413 and TR146 OEC lines and primary OECs incubated with media (gray bars) or the bacterial cocktail MV130 (black bars). Statistically significant differences $(p<0.05)$ between media and MV130 conditions are represented by “*”. Data were obtained from a total of seven independent experiments and we plotted mean values with error bars corresponding to standard errors of the mean (SEM). (B) Figure shows surface expression of CD40 and HLA-DR in H413, TR146 and primary OECs cultured with media, MV130 or IFN $\gamma$ for 48 h, as determined by flow cytometry (black profiles). Isotype specific antibodies were used as negative control (gray profiles). Result shows MFI of a representative experiment out of three independent assays.

primary OECs after bacterial contact. TSLP was only detected in H413 cultures and its production was not modified by bacterial stimulation.

Different studies have shown that under certain inflammatory conditions epithelial cells can express HLA-DR and costimulatory markers (25). To investigate this issue, H413, TR146 and primary OECs were treated with MV130 or with IFN $\gamma$, a well-known HLA-DR inducer, as control. Subsequently, cells were analyzed by flow cytometry for CD80, CD86, CD83, CD40 and HLA-DR expression. OECs did not express CD80,
CD86 or CD83 under any of the assayed conditions (data not shown). CD40 was expressed at high levels in H413 and TR146 cells but not in primary OECs, being unaltered by bacteria or IFN $\gamma$ stimulation (Figure 1B). HLA-DR expression was substantially induced on H413 and TR146 cell lines and in a lower extent in primary OECs when treated with IFN $\gamma$, but invariable when treated with MV130. Overall, these results indicate that OECs were poor responders to the assayed stimuli, and only in the presence of IFN $\gamma$, HLA-DR can be upregulated. 
A
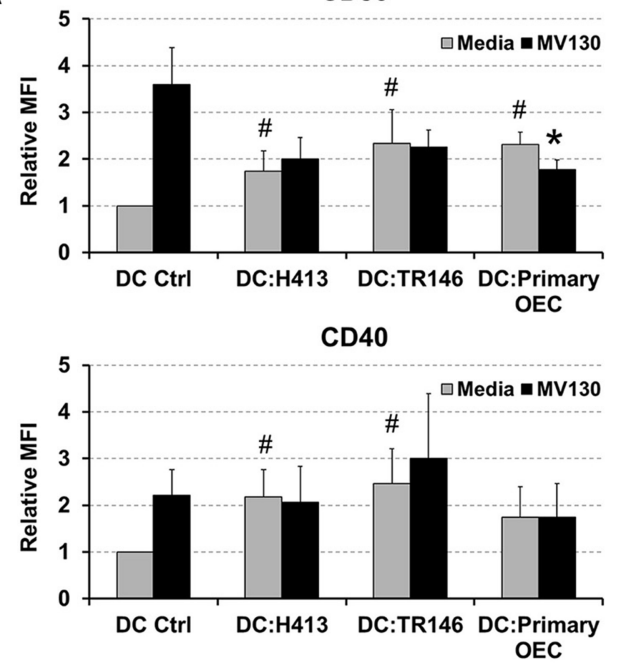

B
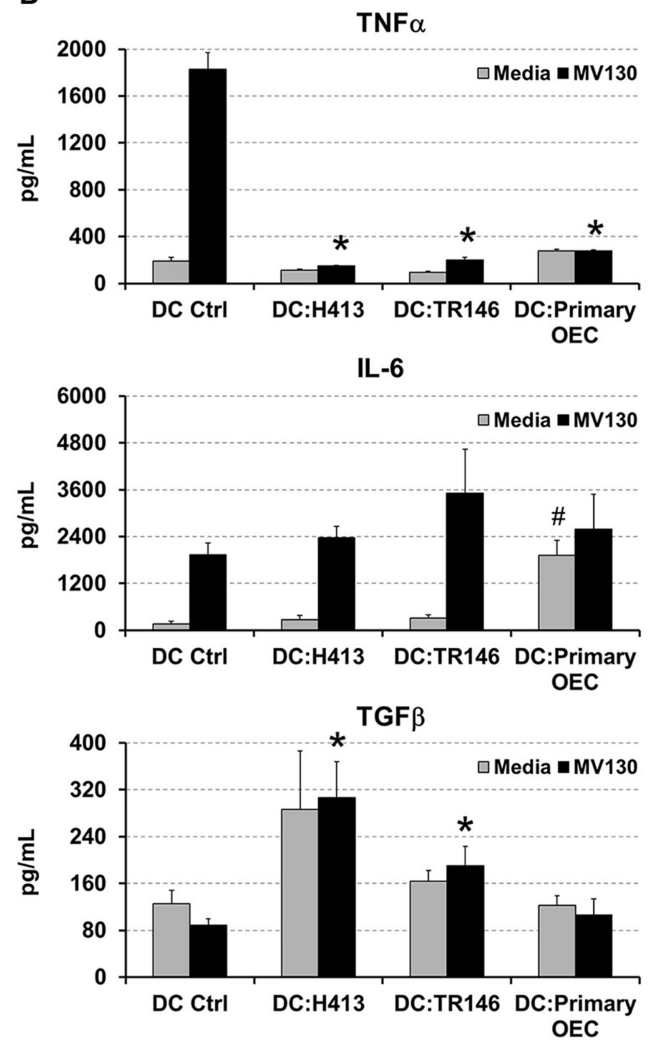

CD80

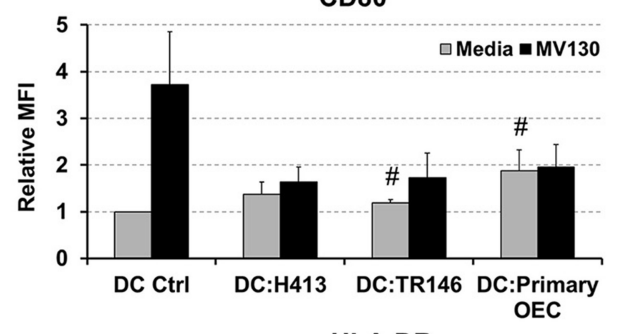

HLA-DR

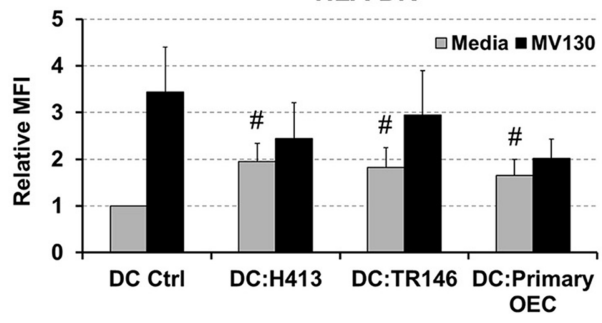

IL-12

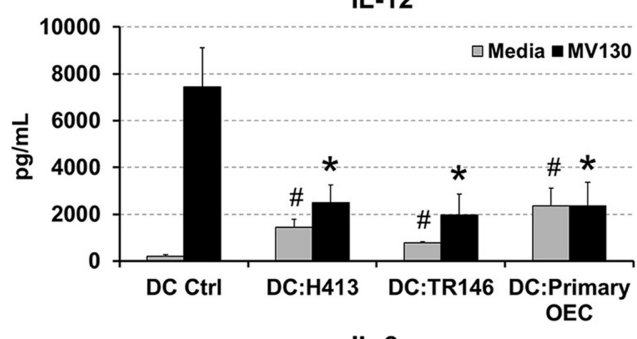

IL-8

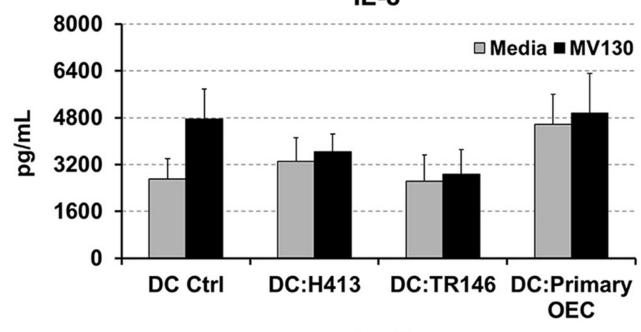

IL-10

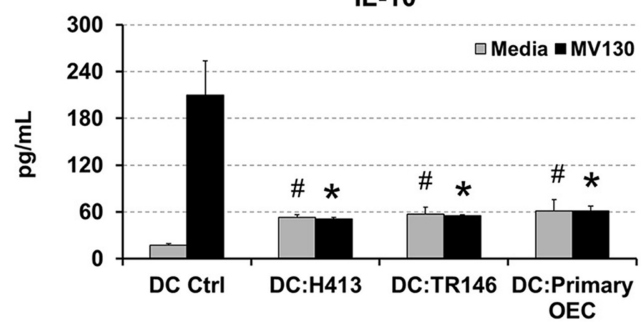

FIGURE 2 | Effect of OECs on DC maturation and cytokine expression. (A) Expression of CD86, CD80, CD40 and HLA-DR in monocyte-derived DCs cultured alone (DC Ctrl) or in co-culture with OECs during 48 h (DC:H413; DC:TR146; DC: primary OECs). Black bars represent cells incubated with MV130 and gray bars represent cells in media. DCs are gated based on CD11c staining. (B) Cytokine secretion by DCs cultured with OECs. Figure shows the levels of TNF $\alpha$, IL-12, IL-6, IL-8, IL-10 and TGF $\beta(\mathrm{pg} / \mathrm{ml})$ determined by ELISA in supernatants of DCs cultured alone (DC Ctrl) or in co-culture with OECs during 48h (DC:H413; DC:TR146; DC: primary OECs). Black bars represent cells incubated with MV130 and gray bars represent cells with media. Statistically significant differences $(p<0.05)$ between the different DC conditions and DC Ctrl were noted as "\#” for media or as "*” for MV130. Data were obtained from a total of four independent experiments and we plotted mean values with error bars corresponding to SEM. 
IFN $\gamma$

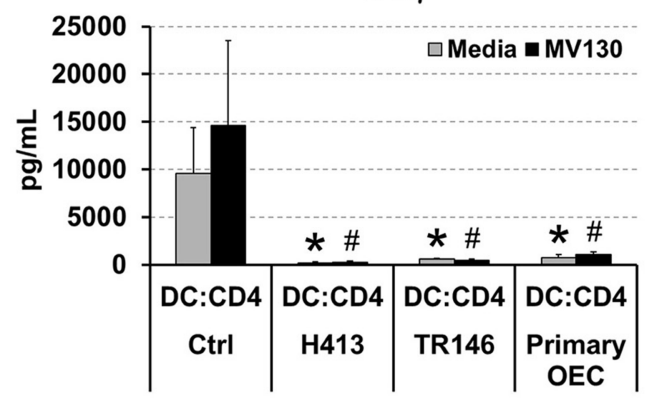

IL-6

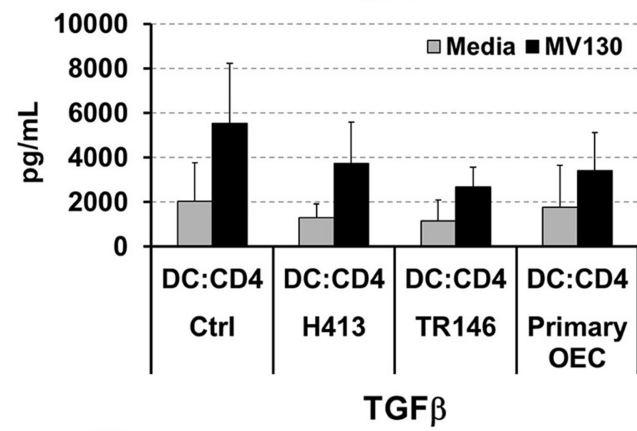

TNF $\alpha$

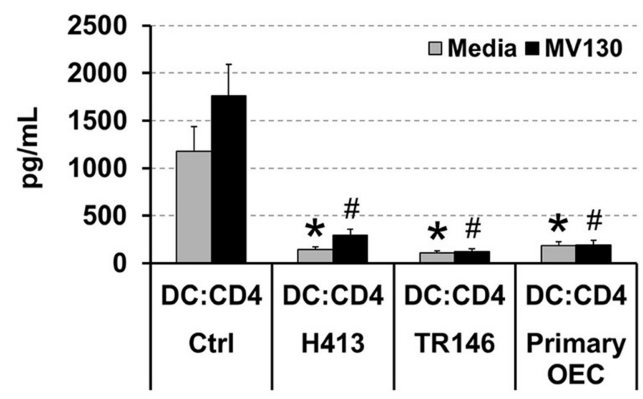

IL-4

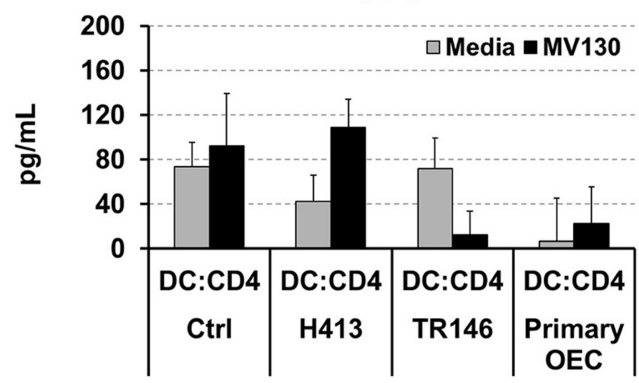

IL-10

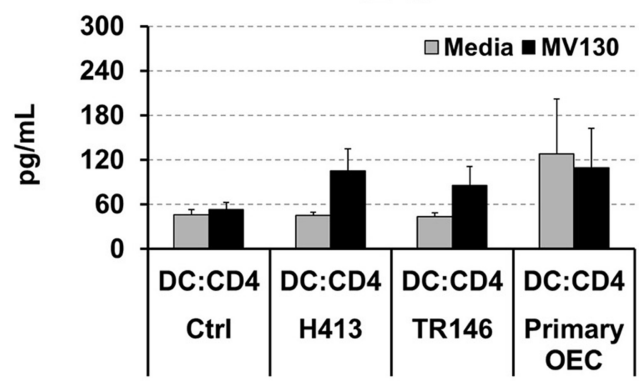

FIGURE 3 | Analysis of cytokines in DC:T cell cultures under OEC conditioning. Figure depicts the levels of IFN $\gamma$, TNF $\alpha$, IL-6, IL-4, TGF $\beta$ and IL-10 detected by ELISA in cultures of naive CD4 T cells activated by allogenic DCs (DC:CD4) alone (controls) or in co-culture with H413, TR146, or primary OECs (DC:OEC) with media (gray bars) or MV130 (black bars). Statistically significant differences $(p<0.05)$ between the different DC:CD4 conditions and DC:CD4 Ctrl were noted as "\#" for media or as "*” for MV130. Data were obtained from a total of three independent experiments and we plotted mean values with error bars corresponding to SEM.

\section{Effect of OECs on Dendritic Cell Maturation and Cytokine Secretion}

Since a crosstalk between epithelial cells and DCs has been described $(6,10)$, we addressed whether OECs could influence the maturation and cytokine production of DCs. These experiments were performed with OECs that were previously treated with or without bacteria and then co-cultured with monocyte-derived DCs, as described in Methods. DCs were also cultured alone with or without the same bacterial cocktail as control. As observed in Figure 2A, MV130 increased the expression of CD86, CD80, CD40, and HLA-DR on DCs cultured alone. In contrast, the increment in expression for these molecules (except for CD40) was greatly reduced when DCs were co-cultured with OECs (DC:OEC) (Figure 2A). Note that bacteria were also present in this co-culture. Interestingly, in the absence of bacteria, OECinstructed DCs increased their expression of CD86, CD40 and HLA-DR compared to DCs alone (Figure 2A).
Figure 2B shows cytokine production in $48 \mathrm{~h}$ culture supernatants in the same co-culture system as above. As expected, control DCs treated with MV130 produced high levels of TNF $\alpha$, IL-12, IL-6 and IL-10. In contrast, DCs co-cultured with OECs and MV130 produced lower levels of TNF $\alpha$, IL-12 or IL-10, while TGF $\beta$ and IL-6 levels increased or remain unmodified. Overall, these results indicated that OECs, independently of bacterial stimulation, may promote DC maturation but holding these cells in a semi-maturation state, as judged by the reduced expression of MHC II and co-stimulatory molecules as well as the impaired production of IL-12 and TNF $\alpha$ after challenging with strong bacterial stimuli.

\section{Effect of OEC Modulation Over DC-Mediated T Cell Polarization}

DCs link innate immunity and adaptive immunity by driving the activation and differentiation of naive $\mathrm{T}$ cells. Thereby, we 
A
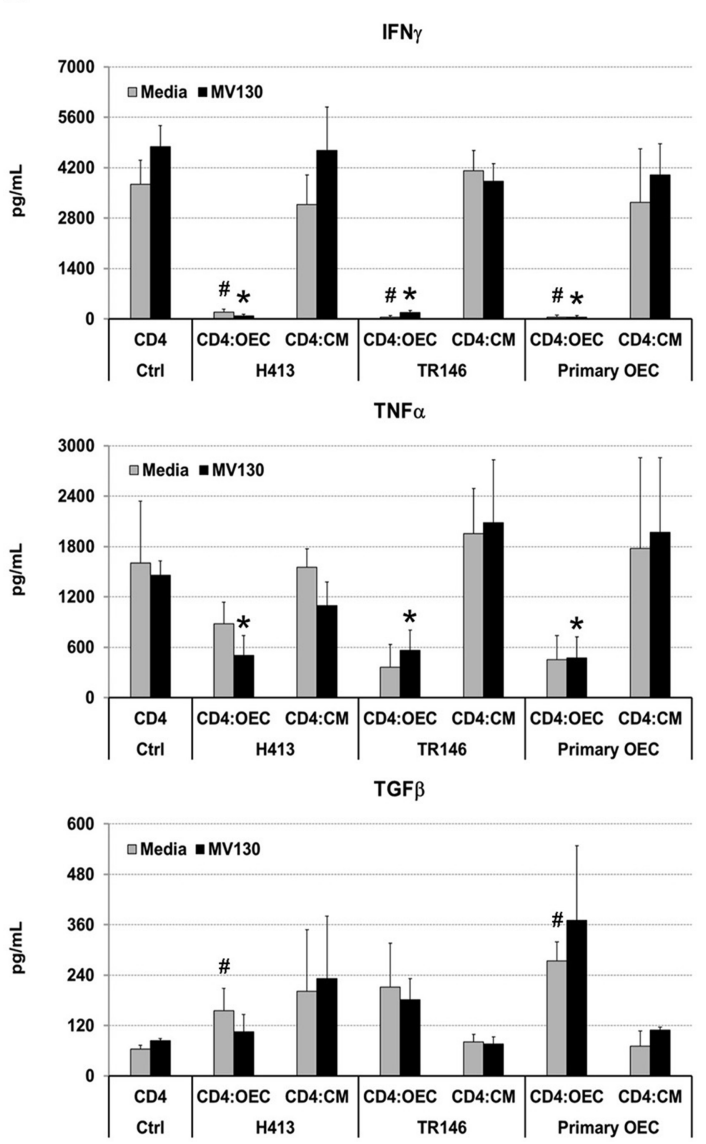

B
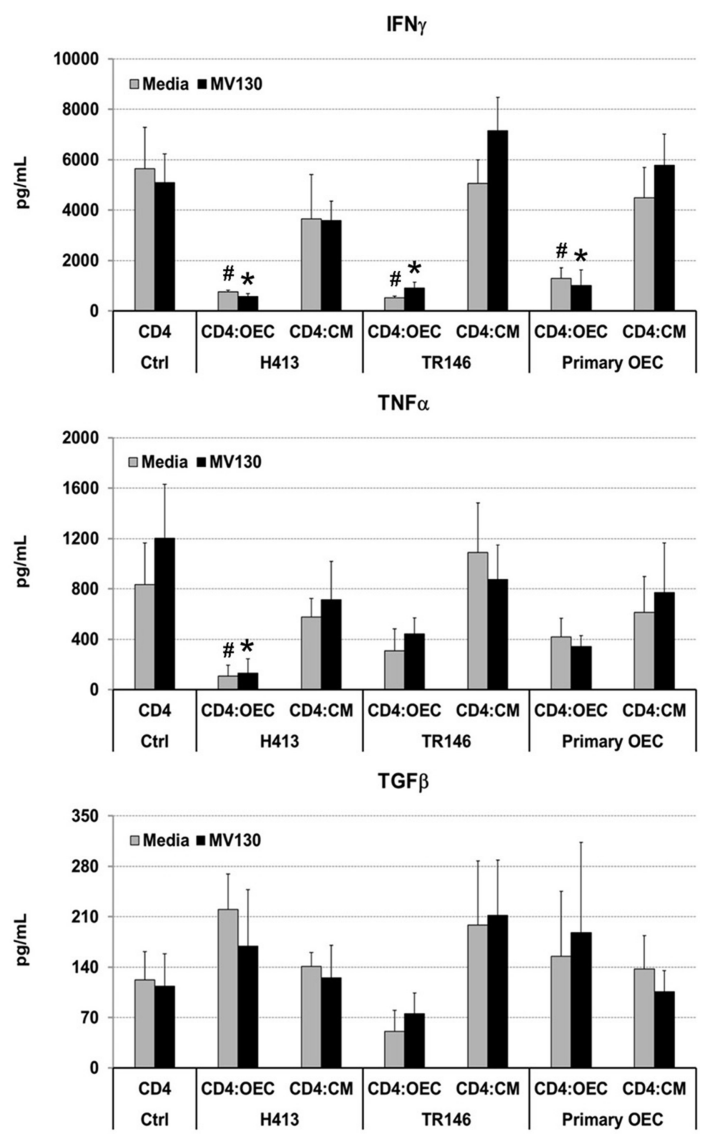

FIGURE 4 | OECs alter the cytokine levels produced by CD4 T cells. Levels of IFN $\gamma$, TNF $\alpha$ and TGF $\beta$ determined by ELISA on cultures consisting of CD3/CD28 activated total CD4 T cells (A) or Th1 cells (B) alone (CD4 Ctrl), in the presence of OEC (CD4:OEC) or their conditioned media (CD4:CM). The experiments were carried out using H413, TR146 cell lines and primary OECs. Media and MV130 conditions are represented by gray and black bars, respectively. Statistically significant differences $(p<0.05)$ between the different CD4 T cells conditions and CD4 T cells Ctrl were noted as "\#” for media or as "*” for MV130. Data were obtained from a total of three independent experiments and we plotted mean values with error bars corresponding to SEM.

evaluated the ability of DCs to activate and polarize naive T cells under OEC conditioning with or without bacteria. To that end, allogenic naive CD4 T cells were cultured for 6 days with DCs alone (controls) or DCs co-cultured with OECs, with or without MV130 as described in Methods, and IFN $\gamma, \mathrm{TNF} \alpha$, IL4 , IL-6, TGF $\beta$ and IL-10 were measured in the resulting culture supernatants. As shown in Figure 3, control cultures containing CD4 T cells and allogenic DCs produced detectable amounts of all these cytokines that remained stable or increased in the presence of bacteria, with the exception of TGF $\beta$, that decreased under bacterial exposure. Interestingly, IFN $\gamma$ and $\mathrm{TNF} \alpha$ were barely detectable in DC:CD4 T cell cultures containing OECs, regardless of the presence of bacteria (Figure 3), in contrast to control DC:T cell that expressed large amounts of these two cytokines (Figure 3). Similar results were observed in the absence of DCs, when CD4 T cells were activated through $\mathrm{CD} 3 / \mathrm{CD} 28$ stimulation in the presence of OECs. However, this inhibitory effect was not observed when activated CD4 T cells were incubated only with OECs culture media, hereafter
OEC-conditioned media (CD4:CM), pointing to a direct effect of OECs on T cells (Supplemental Figure 1).

Next, we analyzed if OECs, with or without bacterial stimuli, could also suppress IFN $\gamma$ production by $\mathrm{T}$ cells that have already undergone differentiation. To that end, we activated total CD4 T cells and Th1 cells (differentiated in vitro, details in Methods) with anti-CD3/CD28 antibodies, alone (CD4 control) or in the presence of OECs (CD4:OEC) or OEC-conditioned media (CD4:CM), including conditions with and without MV130. After $48 \mathrm{~h}$, we assessed CD4 T cell responses by determining IFN $\gamma$, $\mathrm{TNF} \alpha$, and TGF $\beta$ in cell culture supernatants. As shown in Figure 4, CD3/CD28 stimulation of total CD4 T cells or Th1 cells triggered the secretion of vast amounts of IFN $\gamma$ that were readily suppressed by the presence of OECs but not by their conditioned media. A similar suppression was also observed with respect to the production of $\mathrm{TNF} \alpha$, albeit to a lesser extent. By contrast, TGF $\beta$ was in general increased in CD4:OEC co-cultures especially when using primary OECs. Again, the presence or absence of bacteria did not alter these results (Figure 4). 
TABLE 1 | Summary of the cytokines produced by OEC/DC/CD4-culture systems in the presence or absence of MV130.

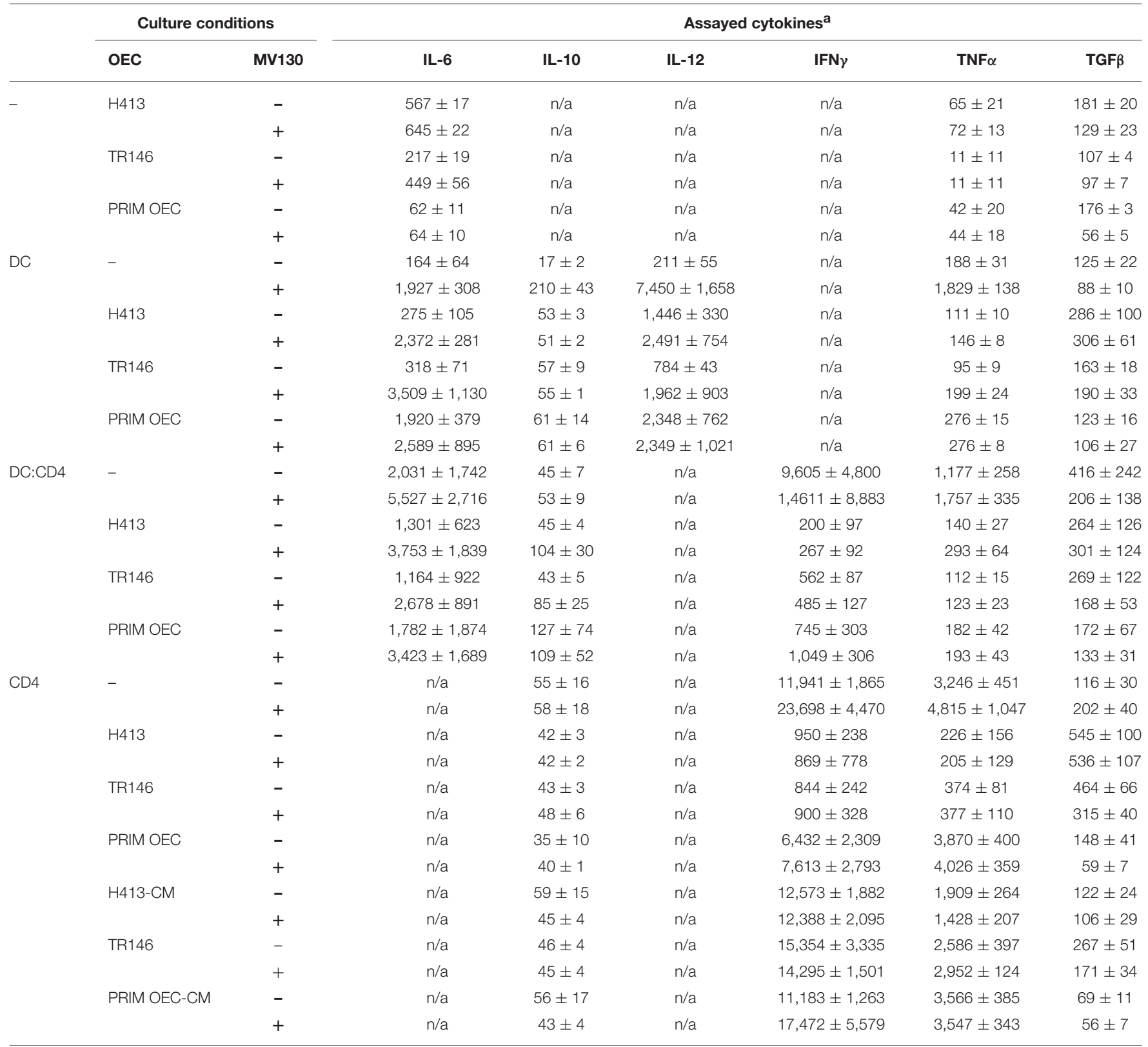

${ }^{a}$ Data are represented as mean \pm SEM. n/a: not available. Units in pg/ml.

A summary of the most representative cytokines (IL-6, IL10, IL-12, IFN $\gamma$, TNF $\alpha$ and TFG $\beta$ ) produced in the presence or absence of MV130 during different culture conditions, is shown in Table 1.

\section{Analysis of the OEC-Mediated Suppression of CD4 T Cell Responses}

To gain insight into the possible mechanism(s) by which OECs suppressed CD4 $\mathrm{T}$ cells IFN $\gamma$ and $\mathrm{TNF} \alpha$ production, different experiments were carried out using $\mathrm{CD} 3 / \mathrm{CD} 28$-stimulated $\mathrm{CD} 4 \mathrm{~T}$ cells in co-culture with $\mathrm{H} 413$ cells, as representative OEC and without the inclusion of bacteria. As shown in a representative experiment (Figure 5A), CD4 $\mathrm{T}$ cells expressed high levels of the T cell activation markers CD25 and CD69 upon stimulation, as expected. However, when $\mathrm{H} 413$ cells were present, CD25 was greatly decreased, and CD69 expression was virtually abolished suggesting a defect in $\mathrm{T}$ cell activation. Because of the lower expression of CD25 in co-culture with OECs (H413), the effect of these cells on $\mathrm{T}$ cell proliferation and viability was assessed. As shown in Figure 5B, CD3/CD28-stimulated CD4 T cells were unable to proliferate in the presence of $\mathrm{H} 413$ epithelial cells, without showing any increase in apoptosis or necrosis (Figure 5C).

Next, we asked whether OEC-conditioned CD4 T cells could respond to a new stimulation once they were re-isolated from OEC co-cultures. Thus, CD4 T cells were cultured alone or with 
A
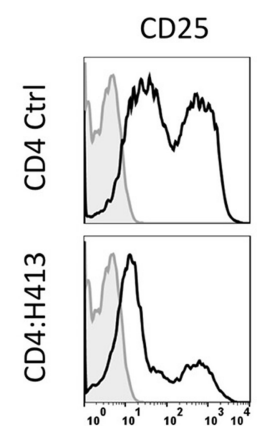

D

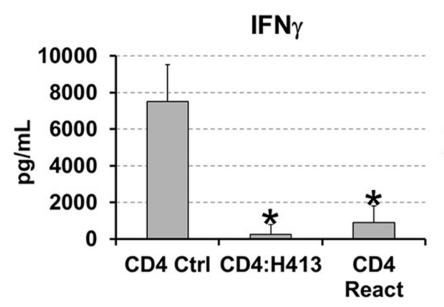

B
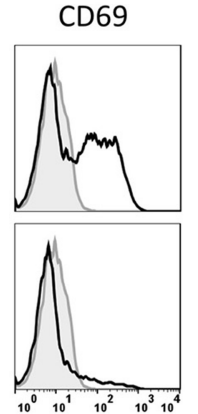

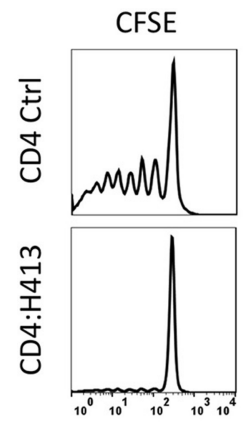

C

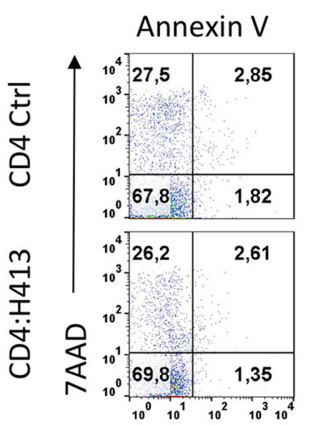

FIGURE 5 | OECs suppressed the activation and proliferation of activated CD4 T cells. (A) Expression of CD25 and CD69 activation markers on CD3/CD28 stimulated CD4 T cells cultured alone or with $\mathrm{H} 413$ cells. (B) CFSE staining and (C) annexin $\mathrm{V}$ and 7-AAD staining of activated CD4 T cells alone (CD4) or in culture with OEC (CD4:H413). (D) IFN $\gamma$, TNF $\alpha$, and TFG $\beta$ on supernatants of CD3/CD28 stimulated CD4 T cell cultures consisting of: control CD4 T cells (CD4 Ctrl); CD4 T cells cultured with $\mathrm{H} 413$ cells (CD4:H413) and the same CD4 T cells isolated from H413 co-cultures and activated again with anti-CD3/CD28 antibodies (CD4 React). Statistically significant differences $(p<0.05)$ between the different CD4 T cells conditions and CD4 T cells Ctrl were noted with "*". Data were obtained from a total of three independent experiments and we plotted mean values with error bars corresponding to SEM.

A

B
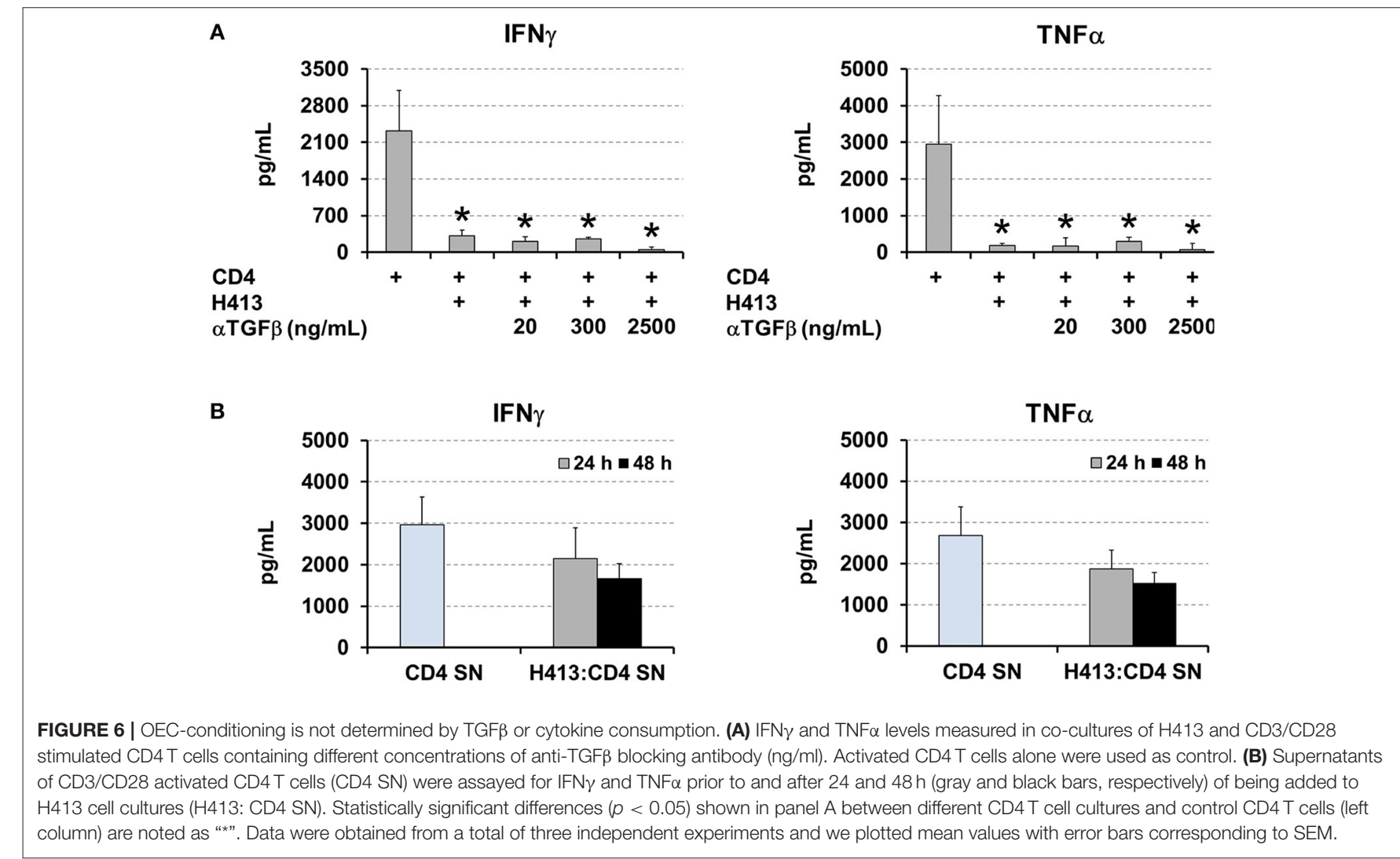

TNF $\alpha$

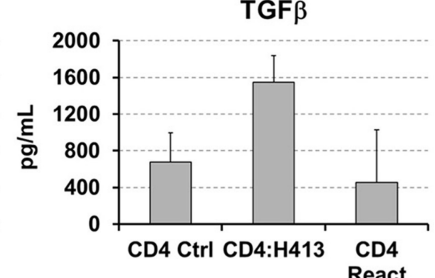


$\mathrm{H} 413$ cells and $48 \mathrm{~h}$ later IFN $\gamma, \mathrm{TNF} \alpha$ and TGF $\beta$ levels were measured. Latter, CD4 T cells were recovered from the culture, rested for $6 \mathrm{~h}$ and stimulated again (reactivated) with antiCD3/CD28 antibodies. After $48 \mathrm{~h}, \mathrm{IFN} \gamma, \mathrm{TNF} \alpha$ and TGF $\beta$ were analyzed in the supernatants. As shown in Figure 5D, reactivated CD4 $\mathrm{T}$ cells produced less amounts of IFN $\gamma$ and TNF $\alpha$ than control activated CD $4 \mathrm{~T}$ cells. In contrast, TFG $\beta$ production was similar to that of control CD4 T cells.

TGF $\beta$ production was active on OECs cultures (Figure 1A) and it was maintained and even increased, in the above various co-culture systems (Figures 2-4). As this cytokine may inhibit $\mathrm{T}$ cell proliferation and Th1 differentiation (26) we examined its role in the above inhibition of IFN $\gamma$ and TNF $\alpha$ production. Thus, the same co-culture system as above (CD3/CD28-stimulated CD4 T cells and H413 epithelial cells) was performed in the presence of increasing amounts of anti-TGF $\beta$ blocking antibodies (Figure 6A). As shown, no effect was found regarding an increase in IFN $\gamma$ and TNF $\alpha$ production as consequence of TGF $\beta$ blocking. Since epithelial cells can respond to IFN $\gamma$ and $\mathrm{TNF} \alpha$ (27), we investigated whether OECs might be depleting both cytokines from the media. To that end, CD3/CD28-stimulated CD4 T cells were cultured for $24 \mathrm{~h}$ and their supernatant added to $\mathrm{H} 413$ cells. After 24 and $48 \mathrm{~h}$ IFN $\gamma$ and TNF $\alpha$ levels were measured and compared with the original supernatant, kept as control. The results shown in Figure 6B indicate that H413 cells could only deplete $\sim 50 \%$ of IFN $\gamma$ and TNF $\alpha$ produced by activated CD 4 T cells.

\section{DISCUSSION}

The relevance of mucosal epithelial cells in the regulation of immune responses, particularly toward the maintenance of tolerance to foreign non-pathogenic antigens, has been highlighted in different studies generally involving the gut mucosa (28) and respiratory mucosa in the context of asthma development [reviewed in (29)]. However, the immunological role of epithelial cells in other mucosa, including the oral mucosae, remains largely understudied. The oral mucosa is a site of intense immunological activity, which also serves as a niche for numerous commensal bacteria. In the present work, we have analyzed the response of oral epithelial cells (OECs) to a cocktail of bacteria (MV130) and their ability to condition the activity of DCs and CD4 T cells. As OECs we used keratinocytes isolated from the inner cheek of healthy volunteers and H413 and TR146 cells, derived from human oral squamous cell carcinomas. H413 and TR146 cells maintain the epithelial characteristics of the parental cells and have been used as a model of oral epithelial cells in diverse studies $(30,31)$. MV130 is a mixture of inactivated whole cell $\mathrm{Gram}^{+}$and $\mathrm{Gram}^{-}$bacteria frequently found in the upper respiratory mucosa (32). We used MV130 for being a known trigger of DC maturation and T cell polarization (21). However, it is worth noting that the genus Streptococci, Haemophilus, and Neisseria, as well as Stapphylococcus aureus, all of them in MV130, are well represented in the commensal flora of the oral cavity (22). Moreover, Streptococcus pneumoniae in MV130 is closely related to the highly prevalent S. mitis and
S. oralis within the oral flora, sharing more than 99\% DNA sequence homology to each others (33).

The experimental settings and most relevant findings obtained in this study are depicted in Figure 7. Stimulating OECs derived from primary cultures or human cell lines with these bacteria did not have a major impact in the production of cytokines such as IL- $1 \beta, T N F \alpha$, and IL-8, which are involved in the initiation of an inflammatory response. Likewise, such a bacteria cocktail did not result in MHC II expression by OECs, although this was readily induced by IFN $\gamma$. Co-stimulatory molecules (CD80/CD86) could not be induced by any assayed stimuli, but OECs expressed significant amounts of constitutive CD40. In contrast, others have described an increased CD80 and CD86 expression in an immortalized oral epithelial cell line, HOK-18A, along with $\mathrm{MHC}$ II expression in response to pathogenic bacteria (20). Expression of CD80/CD86 has also been described in intestinal epithelial cells (IEC) under inflammatory stimulation (34). Moreover, IECs isolated from patients with inflammatory bowel disease (IBD) expressed MHC II, CD80 and CD86 and were found capable of inducing CD4 T cell proliferation and IFN $\gamma$ secretion (35). Thereby we cannot discard that other stimuli could promote the expression of CD80 and CD86 in OECs. In any case, given the expression of CD40 and MHC II, our results indicate that although these OECs might not activate naive CD4 T cells they are clearly ready to crosstalk with effector CD4 T cells and, according to the absence of CD80/CD86, perhaps limit their activity (36).

OECs share location and are in close contact with DCs within the oral mucosa. DCs act as sentinel cells, continuously sampling antigens, and microorganisms to present to T cells, thus bridging innate and adaptive immunity. As expected, DCs treated with the assayed bacteria cocktail reached a mature phenotype characterized by a high expression of CD86, CD80, CD40 and MHC II and a release of pro-inflammatory cytokines such IL-12 and TNF $\alpha$ (21). DCs cultivated in the presence of OECs displayed some features of maturation, judging by the expression of the indicated makers, which were not enhanced by the presence of bacteria. Moreover, the production of inflammatory cytokines (TNF $\alpha$ and IL-12) appeared decreased in DCs co-cultured with OECs even in the presence of bacteria. Overall, these results suggest that OECs modulate the maturation of DCs, making them refractory to bacterial stimulation and holding them in a semi-maturation state. Similar results have been described using Caco-2, a colonic epithelial cell line (8). DCs conditioned by supernatants from Caco- 2 cells treated with bacteria exhibit a semi-mature phenotype and did not produce IL-12 (8). Likewise, renal tubular epithelial cells (ECs) and airway ECs induced a semi-mature phenotype on DCs, which could not be reverted by bacterial stimulation (37-39).

Mature DCs are responsible for activating and initiating effector $\mathrm{T}$ cell responses against foreign antigens, while semimature DCs have been involved in promoting tolerogenic $\mathrm{T}$ cell responses (40). Thereby, we investigated the response and phenotype of allogenic naive CD4T cells activated with DCs in co-culture with OECs, with or without bacterial exposure. While DCs stimulated with bacteria pushed CD4 T cells to produce high levels of IFN $\gamma$ and $\mathrm{TNF} \alpha$, consistent with a 
A

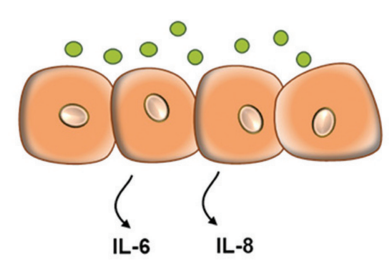

$\uparrow$ IL-6, IL-8

C

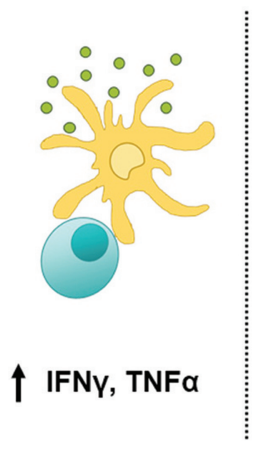

B

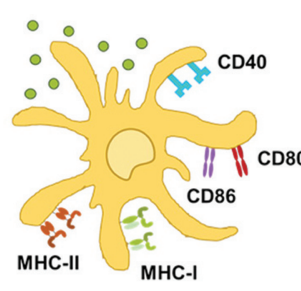

IL-12, TNFa, IL-6, IL-10, CD86, CD80, CD40, HLA-DR

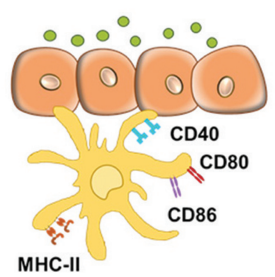

IL-12, TNF $\alpha$, IL-10, CD86, CD80, HLA-DR

D

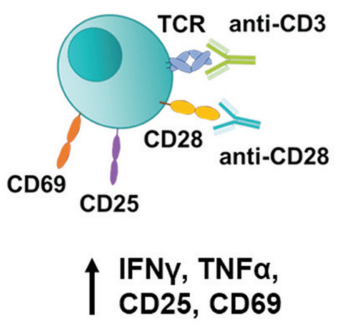

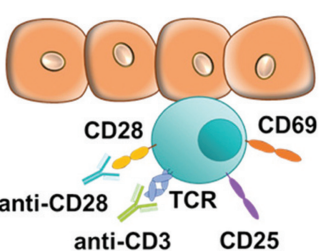

IFNy, TNFa, CD25, CD69
D CD25, CD69

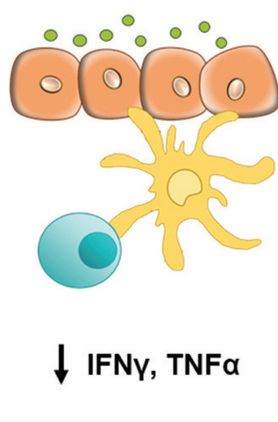

OEC

DC

CD4 T cell

MV130

FIGURE 7 | OEC-mediated immunomodulation under bacterial stimulation. Figure illustrates the experimental settings used in this work and the most relevant findings. (A) OECs response to MV130 stimulation. H413 and TR146 cells but not primary OECs constitutively released IL-6 and IL-8. These cytokines level increased with MV130 stimulation. (B) DCs did not fully mature in the presence of OECs. DC stimulated with MV130 expressed CD80, CD86 and HLA-DR, and released IL-12, IL-10 and TNF $\alpha$ (left), while in co-culture with OECs (right) showed decreased expression of HLA-DR, CD80 and CD86, and decreased release of IL-12, IL-10, and TNF $\alpha$. (C) DCs failed to stimulate allogenic CD4 T cells in the presence of OECs. CD4T cells stimulated with allogenic DCs previously treated with MV130 (left) released IFN $\gamma$ and TNF $\alpha$ but did not when in co-culture with OEC (right). (D) CD4T cell activation was compromised in the presence of OECs. CD3/CD28-activated CD4 T cells expressed CD25 and CD69 and released IFN $\gamma$ and TNF $\alpha$ (left) unlike their counterparts in co-culture with OECs (right).

previous study (21), when OECs were present in the culture a total abrogation of the IFN $\gamma$ released by CD4 $\mathrm{T}$ cells with a concomitant reduction of TNF $\alpha$ was noted. Interestingly, similar results were obtained with OECs in experiments in which naive CD4 T cells were activated using CD3/CD28 signaling in the absence of DCs; therefore ruling out any effect due exclusively to DCs. Abrogation of IFN $\gamma$ and TNF $\alpha$ production was only observed when total CD4 T cells or Th1 polarized cells, were co-cultured with OECs and not with their conditioned media. This suggests a requirement for a direct or a very close contact between OECs and activated T cells to achieve that suppression. CD4 T cells stimulated with anti-CD3/CD28 antibodies were viable in co-cultures with OECs irrespective of the presence of inactivated bacteria, but they did barely express activation markers such as CD25 or CD69 and did not proliferate. This kind of inhibition of $\mathrm{T}$ cell responses has also been reported using other epithelial cells. Human biliary epithelial cells and colonic epithelial cells inhibited $\mathrm{T}$ cell responses without inducing $\mathrm{T}$ cell apoptosis $(15,16)$. Another study demonstrated that renal tubular epithelial cells presented immunosuppressive properties, being able of inhibiting CD4 and CD8 T cell activity, but, in contrast to our findings, inducing $\mathrm{T}$ cell apoptosis in a contactdependent manner (17). Lung epithelial cells have also been reported to inhibit DC-induced $\mathrm{T}$ cell proliferation and cytokine release. This effect was predominantly contact-dependent and partly mediated by TGF $\beta$ (41). In contrast, colonic epithelial cells have been shown to prevent CD4 $\mathrm{T}$ cell activation by professional APCs in a contact-dependent manner but independent of TGF $\beta$ (15). Likewise, TGF $\beta$ did not seem to mediate CD4T cell inhibition by $\mathrm{H} 413$ OECs, as IFN $\gamma$ and TNF $\alpha$ production did not increase by adding TGF $\beta$ blocking antibodies in the culture. The possibility that OECs were consuming the produced IFN $\gamma$ and $\mathrm{TNF} \alpha$ was also unlikely, even though they have been described to express receptors for these cytokines $(42,43)$, as only a minor amount of the IFN $\gamma$ and $\mathrm{TNF} \alpha$ reduction could be explained by this fact.

CD4 T cells recovered from OECs co-cultures were hyporesponsive to re-stimulation with anti-CD3/CD28 antibodies as they were able to produce only low amounts of IFN $\gamma$ and TNF $\alpha$. A similar effect has been observed for CD4 T 
cells in contact with retinal pigmented epithelial cells, which remained unresponsive to new antigenic stimulation (44). In contrast, $\mathrm{T}$ cells recovered from colonic epithelial cell or renal tubular epithelial cell co-cultures were able to respond to a further antigenic stimulation $(15,17)$. Thus, OECs may be promoting a functional inactivation of T cells similar to anergy (45). Anergy is one of the main mechanisms involved in oral tolerance, especially under high antigen concentration, conditions in which Treg induction is poor (46). T cell anergy can be induced by altered antigenic presentation, by antigen recognition in absence of costimulation or by colligation of inhibitory molecules such as PD-1 or CTLA-4 (47-51). However, anergy is mainly induced in naive $\mathrm{T}$ cells while we used total CD4 T cells. Hence, we cannot discard some other phenomena including $\mathrm{T}$ cell exhaustion (52). Thus, the precise mechanism by which OECs rendered $\mathrm{T}$ cells unresponsive remains to be elucidated but it seems to be cell-cell contact dependent and likely facilitated by MHC II and CD40 expression on OECs.

\section{CONCLUSION}

Our results indicate that OECs downregulate some DC functions and suppress local $\mathrm{T}$ cell responses in a rather constitutive manner. This behavior likely evolved to avoid harmful immune responses against residing bacteria and can favor oral treatments aimed to induce immune tolerance, but it needs to be overcome for treatments aimed to enhance or induce immunological protective memory.

Protection from undesired and/or excessive immune responses is of paramount relevance for survival and organisms must have evolved with various mechanisms to achieve it. Currently, those involving the active induction and harness of immune cells with tolerogenic phenotype has focused most of the researcher's attention (53) However, while these mechanisms are crucial and contribute to control immune responses, our results indicate that, overall, they are shadowed by the inherent

\section{REFERENCES}

1. Novak N, Haberstok J, Bieber T, Allam JP. The immune privilege of the oral mucosa. Trends Mol Med. (2008) 14:191-8. doi: 10.1016/j.molmed.2008.03.001

2. Allam JP, Stojanovski G, Friedrichs N, Peng W, Bieber T, Wenzel J, et al. Distribution of Langerhans cells and mast cells within the human oral mucosa: new application sites of allergens in sublingual immunotherapy? Allergy. (2008) 63:720-7. doi: 10.1111/j.1398-9995.2007.0 1611.x

3. Hovav AH. Dendritic cells of the oral mucosa. Mucosal Immunol. (2014) 7:27-37. doi: 10.1038/mi.2013.42

4. Swamy M, Jamora C, Havran W, Hayday A. Epithelial decision makers: in search of the 'epimmunome'. Nat Immunol. (2010) 11:656-65. doi: 10.1038/ni.1905

5. Rescigno M. Intestinal epithelial cells control dendritic cell function. J Pediatr Gastroenterol Nutr. (2008) 46: E17-9. doi: 10.1097/01.mpg.0000313831.09089.36

6. Rescigno M. Dendritic cell-epithelial cell crosstalk in the gut. Immunol Rev. (2014) 260:118-28. doi: 10.1111/imr.12181 ability of epithelial cells to restrain uncontrolled immune cell responses.

\section{DATA AVAILABILITY}

All datasets generated for this study are included in the manuscript and/or the Supplementary Files.

\section{AUTHOR CONTRIBUTIONS}

EL and PR: conceptualization. MM-A, JS-T, MG-P, AT-G, and JS: methodology. MM-A, JS-T, JS, EL, and PR: investigation. JS-T, MG-P, and EL: writing-original draft. EL, JS, and PR: final writing and editing.

\section{ACKNOWLEDGMENTS}

We wish to thank the Spanish Department of Science at MINECO to support this research through grant IPT-2012-0639090000 to PR and JS and through grant BIO2014:54164R. We thank Dr. Pilar Zuluaga for help with statistics.

\section{SUPPLEMENTARY MATERIAL}

The Supplementary Material for this article can be found online at: https://www.frontiersin.org/articles/10.3389/fimmu. 2019.01434/full\#supplementary-material

Figure S1 | OEC instruction alters cytokine profiles in CD3/CD28-activated naive CD4 T cells. We examined the levels of IFN $\gamma$, TNF $\alpha$, IL-2, IL-4, TGF $\beta$ and IL-10 by ELISA on cultures consisting of CD3/CD28-activated naive CD4 T cells alone (CD4 $\mathrm{Ctrl})$, in the presence of OEC (CD4:OEC) or their conditioned media (CD4:CM). The experiments were carried out using H413, TR146 cell lines and primary OECs. Media and MV130 conditions are represented by gray and black bars, respectively. Data were obtained from a total of four independent experiments and we plotted mean values with error bars corresponding to SEM. Statistically significant differences $(p<0.05)$ between the different CD4 T cells conditions and CD4 T cells Ctrl were noted as "\#" for media or as "*" for MV130.
7. Iliev ID, Mileti E, Matteoli G, Chieppa M, Rescigno M. Intestinal epithelial cells promote colitis-protective regulatory T-cell differentiation through dendritic cell conditioning. Mucosal Immunol. (2009) 2:340-50. doi: 10.1038/mi.2009.13

8. Rimoldi M, Chieppa M, Salucci V, Avogadri F, Sonzogni A, Sampietro $\mathrm{GM}$, et al. Intestinal immune homeostasis is regulated by the crosstalk between epithelial cells and dendritic cells. Nat Immunol. (2005) 6:507-14. doi: 10.1038/ni1192

9. Iliev ID, Spadoni I, Mileti E, Matteoli G, Sonzogni A, Sampietro GM, et al. Human intestinal epithelial cells promote the differentiation of tolerogenic dendritic cells. Gut. (2009) 58:1481-9. doi: 10.1136/gut.2008.175166

10. Soumelis V, Reche PA, Kanzler H, Yuan W, Edward G, Homey B, et al. Human epithelial cells trigger dendritic cell mediated allergic inflammation by producing TSLP. Nat Immunol. (2002) 3:673-80. doi: 10.1038/ni805

11. Blumberg RS, Lencer WI, Zhu X, Kim HS, Claypool S, Balk $\mathrm{SP}$, et al. Antigen presentation by intestinal epithelial cells. Immunol Lett. (1999) 69:7-11. doi: 10.1016/S0165-2478(99) 00093-0

12. Telega GW, Baumgart DC, Carding SR. Uptake and presentation of antigen to $\mathrm{T}$ cells by primary colonic epithelial cells in normal and 
diseased states. Gastroenterology. (2000) 119:1548-59. doi: 10.1053/gast.2000. 20168

13. Thelemann C, Eren RO, Coutaz M, Brasseit J, Bouzourene H, Rosa M, et al. Interferon-gamma induces expression of MHC class II on intestinal epithelial cells and protects mice from colitis. PLoS ONE. (2014) 9:e86844. doi: 10.1371 /journal.pone. 0086844

14. Mulder DJ, Pooni A, Mak N, Hurlbut DJ, Basta S, Justinich CJ. Antigen presentation and MHC class II expression by human esophageal epithelial cells: role in eosinophilic esophagitis. Am J Pathol. (2011) 178:744-53. doi: 10.1016/j.ajpath.2010.10.027

15. Cruickshank SM, McVay LD, Baumgart DC, Felsburg PJ, Carding SR. Colonic epithelial cell mediated suppression of CD4 T cell activation. Gut. (2004) 53:678-84. doi: 10.1136/gut.2003.029967

16. Cruickshank SM, Southgate J, Selby PJ, Trejdosiewicz LK. Inhibition of $\mathrm{T}$ cell activation by normal human biliary epithelial cells. J Hepatol. (1999) 31:1026-33. doi: 10.1016/S0168-8278(99) 80315-8

17. Demmers MW, Korevaar SS, Roemeling-van Rhijn M, van den Bosch TP, Hoogduijn MJ, Betjes MG, et al. Human renal tubular epithelial cells suppress alloreactive T cell proliferation. Clin Exp Immunol. (2015) 179:509-19. doi: $10.1111 /$ cei.12469

18. Dugger K, Lowder TW, Tucker TA, Schwiebert LM. Epithelial cells as immune effector cells: the role of CD40. Semin Immunol. (2009) 21:289-92. doi: 10.1016/j.smim.2009.06.002

19. Propst SM, Denson R, Rothstein E, Estell K, Schwiebert LM. Proinflammatory and Th2-derived cytokines modulate CD40-mediated expression of inflammatory mediators in airway epithelia: implications for the role of epithelial CD40 in airway inflammation. J Immunol. (2000) 165:2214-21. doi: 10.4049/jimmunol.165.4.2214

20. Han DC, Huang GT, Lin LM, Warner NA, Gim JS, Jewett A. Expression of MHC Class II, CD70, CD80, CD86 and pro-inflammatory cytokines is differentially regulated in oral epithelial cells following bacterial challenge. Oral Microbiol Immunol. (2003) 18:350-8. doi: 10.1046/j.0902-0055.2003.00094.x

21. Cirauqui C, Benito-Villalvilla C, Sanchez-Ramon S, Sirvent S, DiezRivero CM, Conejero L, et al. Human dendritic cells activated with MV130 induce Th1, Th17 and IL-10 responses via RIPK2 and MyD88 signalling pathways. Eur J Immunol. (2018) 48:180-93. doi: 10.1002/eji.2017 47024

22. Jia G, Zhi A, Lai PFH, Wang G, Xia Y, Xiong Z, et al. The oral microbiota - a mechanistic role for systemic diseases. Br Dent J. (2018) 224:447-55. doi: $10.1038 /$ sj.bdj.2018.217

23. Garcia Gonzalez LA, Arrutia Diez F. Mucosal bacterial immunotherapy with MV130 highly reduces the need of tonsillectomy in adults with recurrent tonsillitis. Hum Vaccin Immunother. (2019) 19:1-4. doi: 10.1080/21645515.2019.1581537

24. Michalczyk A, Varigos G, Smith L, Ackland ML. Fresh and cultured buccal cells as a source of mRNA and protein for molecular analysis. Biotechniques. (2004) 37:262-4; 266-9. doi: 10.2144/04372RR03

25. Kambayashi T, Laufer TM. Atypical MHC class II-expressing antigenpresenting cells: can anything replace a dendritic cell? Nat Rev Immunol. (2014) 14:719-30. doi: 10.1038/nri3754

26. Gorelik L, Constant S, Flavell RA. Mechanism of transforming growth factor beta-induced inhibition of T helper type 1 differentiation. J Exp Med. (2002) 195:1499-505. doi: 10.1084/jem.20012076

27. Shirey KA, Jung JY, Maeder GS, Carlin JM. Upregulation of IFNgamma receptor expression by proinflammatory cytokines influences IDO activation in epithelial cells. J Interferon Cytokine Res. (2006) 26:53-62. doi: $10.1089 /$ jir.2006.26.53

28. Mowat AM. Anatomical basis of tolerance and immunity to intestinal antigens. Nat Rev Immunol. (2003) 3:331-41. doi: 10.1038/ nri1057

29. Wosen JE, Mukhopadhyay D, Macaubas C, Mellins ED. Epithelial MHC class II expression and its role in antigen presentation in the gastrointestinal and respiratory tracts. Front Immunol. (2018) 9:2144. doi: 10.3389/fimmu.2018.02144

30. Yee M, Kim S, Sethi P, Duzgunes N, Konopka K. Porphyromonas gingivalis stimulates IL-6 and IL-8 secretion in GMSM-K, HSC-3 and H413 oral epithelial cells. Anaerobe. (2014) 28:62-7. doi: 10.1016/j.anaerobe.2014. 05.011

31. Bashyal S, Seo JE, Keum T, Noh G, Choi YW, Lee S. Facilitated permeation of insulin across TR146 cells by cholic acid derivatives-modified elastic bilosomes. Int J Nanomed. (2018) 13:5173-86. doi: 10.2147/IJN.S 168310

32. Alecsandru D, Valor L, Sanchez-Ramon S, Gil J, Carbone J, Navarro J, et al. Sublingual therapeutic immunization with a polyvalent bacterial preparation in patients with recurrent respiratory infections: immunomodulatory effect on antigen-specific memory CD4+ T cells and impact on clinical outcome. Clin Exp Immunol. (2011) 164:100-7. doi: 10.1111/j.1365-2249.2011. 04320.x

33. Kawamura Y, Hou XG, Sultana F, Miura H. Ezaki T. Determination of 16 S rRNA sequences of Streptococcus mitis and Streptococcus gordonii and phylogenetic relationships among members of the genus Streptococcus. Int $J$ Syst Bacteriol. (1995) 45:406-8. doi: 10.1099/00207713-45-2-406

34. Hershberg RM, Mayer LF. Antigen processing and presentation by intestinal epithelial cells - polarity and complexity. Immunol Today. (2000) 21:123-8. doi: 10.1016/S0167-5699(99)01575-3

35. Dotan I, Allez M, Nakazawa A, Brimnes J, Schulder-Katz M, Mayer L. Intestinal epithelial cells from inflammatory bowel disease patients preferentially stimulate CD4+ T cells to proliferate and secrete interferongamma. Am J Physiol Gastrointest Liver Physiol. (2007) 292: G1630-40. doi: 10.1152 /ajpgi.00294.2006

36. Schwartz RH. T cell anergy. Annu Rev Immunol. (2003) 21:305-34. doi: 10.1146/annurev.immunol.21.120601.141110

37. Kronsteiner B, Peterbauer-Scherb A, Grillari-Voglauer R, Redl H, Gabriel $C$, van Griensven $M$, et al. Human mesenchymal stem cells and renal tubular epithelial cells differentially influence monocyte-derived dendritic cell differentiation and maturation. Cell Immunol. (2011) 267:30-8. doi: 10.1016/j.cellimm.2010.11.001

38. Papazian D, Chhoden T, Arge M, Vorup-Jensen T, Nielsen CH, Lund $\mathrm{K}$, et al. Effect of polarization on airway epithelial conditioning of monocytederived dendritic cells. Am J Respir Cell Mol Biol. (2015) 53:368-77. doi: 10.1165/rcmb.2014-0183OC

39. Papazian D, Wagtmann VR, Hansen S, Wurtzen PA. Direct contact between dendritic cells and bronchial epithelial cells inhibits $\mathrm{T}$ cell recall responses towards mite and pollen allergen extracts in vitro. Clin Exp Immunol. (2015) 181:207-18. doi: 10.1111/cei.12611

40. Lutz MB, Schuler G. Immature, semi-mature and fully mature dendritic cells: which signals induce tolerance or immunity? Trends Immunol. (2002) 23:445-9. doi: 10.1016/S1471-4906(02)02281-0

41. Wang H, Su Z, Schwarze J. Healthy but not RSV-infected lung epithelial cells profoundly inhibit $T$ cell activation. Thorax. (2009) 64:283-90. doi: $10.1136 /$ thx.2007.094870

42. Valente G, Ozmen L, Novelli F, Geuna M, Palestro G, Forni G, et al. Distribution of interferon-gamma receptor in human tissues. Eur J Immunol. (1992) 22:2403-12. doi: 10.1002/eji.1830220933

43. Schling P, Rudolph C, Heimerl S, Fruth S, Schmitz G. Expression of tumor necrosis factor alpha and its receptors during cellular differentiation. Cytokine. (2006) 33:239-45. doi: 10.1016/j.cyto.2006.02.007

44. Gregerson DS, Heuss ND, Lew KL, McPherson SW, Ferrington DA. Interaction of retinal pigmented epithelial cells and CD4 T cells leads to T-cell anergy. Invest Ophthalmol Visual Sci. (2007) 48:4654-63. doi: $10.1167 /$ iovs.07-0286

45. Macian F, Im SH, Garcia-Cozar FJ, Rao A. T-cell anergy. Curr Opin Immunol. (2004) 16:209-16. doi: 10.1016/j.coi.2004.01.013

46. Tordesillas L, Berin MC. Mechanisms of oral tolerance. Clin Rev Allergy Immunol. (2018) 55:107-17. doi: 10.1007/s12016-018-8680-5

47. Sloan-Lancaster J, Evavold BD, Allen PM. Induction of T-cell anergy by altered T-cell-receptor ligand on live antigen-presenting cells. Nature. (1993) 363:156-9. doi: $10.1038 / 363156 \mathrm{a} 0$

48. Appleman LJ, Boussiotis VA. T cell anergy and costimulation. Immunol Rev. (2003) 192:161-80. doi: 10.1034/j.1600-065X.2003.00009.x

49. Butte MJ, Keir ME, Phamduy TB, Sharpe AH, Freeman GJ. Programmed death-1 ligand 1 interacts specifically with the B7-1 costimulatory molecule to inhibit $\mathrm{T}$ cell responses. Immunity. (2007) 27:111-22. doi: 10.1016/j.immuni.2007.05.016 
50. Greenwald RJ, Boussiotis VA, Lorsbach RB, Abbas AK, Sharpe AH. CTLA-4 regulates induction of anergy in vivo. Immunity. (2001) 14:145-55. doi: 10.1016/S1074-7613(01) 00097-8

51. Fife BT, Bluestone JA. Control of peripheral T-cell tolerance and autoimmunity via the CTLA-4 and PD-1 pathways. Immunol Rev. (2008) 224:166-82. doi: 10.1111/j.1600-065X.2008. 00662.x

52. Wherry EJ. $\mathrm{T}$ cell exhaustion. Nat Immunol. (2011) 12:492-9. doi: 10.1038/ni.2035

53. Mowat AM. To respond or not to respond - a personal perspective of intestinal tolerance. Nat Rev Immunol. (2018) 18:405-15. doi: 10.1038/s41577-018-0002-x
Conflict of Interest Statement: JS was employed by company Inmunotek.

The remaining authors declare that the research was conducted in the absence of any commercial or financial relationships that could be construed as a potential conflict of interest.

Copyright (C) 2019 Molero-Abraham, Sanchez-Trincado, Gomez-Perosanz, TorresGomez, Subiza, Lafuente and Reche. This is an open-access article distributed under the terms of the Creative Commons Attribution License (CC BY). The use, distribution or reproduction in other forums is permitted, provided the original author(s) and the copyright owner(s) are credited and that the original publication in this journal is cited, in accordance with accepted academic practice. No use, distribution or reproduction is permitted which does not comply with these terms. 